\title{
Modernizmden Postmodernizme İktisat
}

\section{Economics: From Modernism to Postmodernism}

\author{
Hasan BAKIR ${ }^{1} \oplus$, Görkem BAHTIYAR ${ }^{2} \odot$
}

\section{ÖZ}

Neoklasik iktisat, günümüzün hâkim iktisat anlayışıdır. Pozitivist bir metodoloji üzerine temellenen Neoklasik iktisat, ortaya attığı teorilerin bilimsel, evrensel ve rasyonel olduğunu iddia etmektedir. Aydınlanma düşüncesinin temelinde yer alan, olgucu analiz ile insanın çevresine hâkim olacağı iddiası ve dolayısıyla modernizm, bu bakış açısının gelişmesinde önemli bir yere sahiptir. Ancak, modernizmin kişilerden bağımsız ve gözlemlenebilir olgularla açıklanan gerçek dünya görüşünü ifade eden pozitivist yönteme dayanan bu hâkim iktisat anlayışı, karşı argümanlarını da beraberinde getirmiştir. Insanın sosyal çevresinin de doğal çevre gibi pozitif çıkarımlar ile kolaylıkla şekillendirilmesi düşüncesi sorunlu görülmektedir. İktisatta tek bir doğrudan söz edilemeyeceği tartışması başlatılmış ve farklı yaklaşımları da içeren çoğulcu bir bakış açısı daha sonra gündeme gelmiştir. Bu süreçle birlikte tek doğrunun yerini çeşitleme ve farklılı, temsili bireyin yerini holistik yaklaşım almakta, bireylerin duygu, düşünce dünyaları ve kültürel bağlam tekrar analiz konusu edilmektedir. Postmodernist bir ton taşıyan bu itirazın da dikkate alınması, iktisadın kendisine ilişkin kavrayışımızı kuvvetlendirmesi açısından önemlidir. Bu süreçte, holistik yaklaşımı savunan Orijinal Kurumsal İktisadın özellikle evrim vurgusuyla birlikte ön plana çıkması söz konusudur. Kurumsalcılığın yanında, yine ahlakzihniyet-iktisat ilişkisini inceleyen Yorumsamacı yaklaşımın da tekrar ele alınması gerekmektedir. Bu çalışmanın amacı da modernizmden postmodernizme bir süreç olarak iktisadın serüvenini ortaya koymaktır.

Anahtar kelimeler: Modernizm, Postmodernizm, Iktisadi düşünce, Olguculuk, Metodoloji

JEL Sınıflaması: B10, B13, N01

\section{ABSTRACT}

The dominant form of theory in the world of economics today, namely, the Neoclassical economics, claims its theories are universal, scientific and rational. Relying on the positivist methodology, the claim that humanity will be able to dominate the environment through positive analysis, which is one of the tenets of the enlightenment and hence modernism has an important place in the development of this perspective in economics. However, the idea that the social environment of man could easily be
'Doç. Dr., Bursa Uludağ Universitesi, Sosyal Bilimler Meslek Yüksekokulu, Bursa, Türkiye ${ }^{2}$ Dr. Öğr. Üyesi, Bursa Uludağ Üniversitesi, İktisadi ve İdari Bilimler Fakültesi, Bursa, Türkiye

ORCID: H.B. 0000-0002-8248-6643; G.B. $0000-0002-5092-6819$

Sorumlu yazar/Corresponding author: Hasan BAKIR,

Bursa Uludağ Üniversitesi Sosyal Bilimler Meslek Yüksekokulu, Ali Osman Sönmez Kampüsü Osmangazi, Bursa, Türkiye

E-posta/E-mail: hasanbakir@uludag.edu.tr

Başvuru/Submitted: 03.05.2021 Revizyon Talebi/Revision Requested: 14.06.2021

Son Revizyon/Last Revision Received: 19.06.2021

Kabul/Accepted: 22.11 .2021

Atıf/Citation: Bakir, H., \& Bahtiyar, G. (2021). Modernizmden postmodernizme iktisat. Istanbul iktisat Dergisi - Istanbul Journal of Economics, $71(2), 341-366$.

https://doi.org/10.26650/ISTJECON2021-932202 
manipulated with positive inferences like those in the natural sciences seems problematic. The debate over whether it is possible to mention of single positive facts in economic life started long ago and more pluralistic points of view flourished later. Within this process, diversity and difference replaces the single fact positivism, and methodological individualism is replaced by a more holistic approach. At the same time individuals' thoughts and emotions as well as cultural norms of different societies are subjects of scrutiny again. In this vein, the Original Institutional Economics and the Heuristic approach to economics and mentality came into the fore again. The aim of this study is to present the evolution of economics from modernism to postmodernism as a disciplined thought process.

Keywords: Modernism, Postmodernism, Economic thought, Positivism, Methodology

JEL Classification: B10, B13, N01

\section{EXTENDED ABSTRACT}

From Classical Economic Thought of the 18th century to today's New Consensus, the science of economics has come a long way. There are various colors in the pallet of the discipline and they all represent different methodological frameworks. At this point in time, Neoclassical economics, which is the dominant form of theory building in the world of economics today bases its arguments on a positivist methodology, claiming its theories are universal, scientific and rational. However, the struggle for mathematical modelling which is one of the most profound features of the Neoclassical view, came with sacrifices. For instance, one can observe that in its pursuit of formalization, economics reduces relations in a society to mere man-object level, thus, mostly excluding the social side of economic transactions. An economic argumentation must encompass the relation of man to man, and man with the society. It is evident that under this quest for formalization lies the methodological understanding which has its roots in modernist thinking. That is the claim that humanity will be able to dominate its environment through positive analysis, which is one of the tenets of the enlightenment and hence modernism has an important place in the development of this perspective in economics. However, with this economic mentality, came some counter arguments, too. Because of the devastating wars, economic crises, poverty, inequality, famines etc. the reign of this modernist thinking was challenged from a number of points of view. It was seen that modernism was not the answer to the problems that are faced by humanity. Furthermore, it brought with it a new set of problems, some of them are still waiting to be solved. For once, the idea that the social environment of man could easily be manipulated 
with positive inferences like those in the natural sciences seems problematic. For once, a total understanding and modelling the human economic system universally is a goal which might be impossible to achieve. And this goal could not be reached yet as evidenced by various economic crises. Moreover, differing systems of ethics and mentality bear different economic outcomes. Thus, it is difficult to pursue analyses that oust the concept of ethics in economics. As one can observe the reflections of the modernist thinking in economics, one can see the implications of the views criticizing modernism for the discipline of economics as well. The ciritics of Neoclasical economics emphasise diversity instead of single fact positivism and holism instead of methodological individualism. At the same time individuals' thoughts and emotions as well as cultural norms of different societies became objects of scrutiny again. These kinds of objections might be considered in the context of post-modernist thinking in social sciences and taking this postmodernist objection into account may strengthen one's understanding of economics itself. The aim of this study is to present the evolution of economics (taking into account ethics-economics discourse) as a process taking place from modernism to postmodernism in the universe of social thought. Postmodernism, which emerged as a reaction to modernism since the mid-1950s, made its impact felt over time and emerged as an alternative discourse against modernism. Postmodernism is one of the central oppositions to modernist thinking today. Postmodernist thinkers reject the abstractions and assumptions made by modernist thought to reach a universal truth, instead focusing on diversity and difference. The concepts of balance, uncertainty and rationality of modernist economists have been criticized seriously in this sense. Also, in this vein, it is necessary to abandon the approach of homo economicus, which is essentially a modernist conception, but does not seem to fit the reality. Postmodernism brings to the fore more holistic understandings instead of methodological individualism. 


\section{Giriş}

Akıl ve bilimin ilahi olanın yerini alması şeklindeki iddia, aydınlanma düşüncesinin temelini oluşturmaktadır. Bir aydınlanma düşünürü olmamasına rağmen, "tüm tanrılar öldü" derken Friedrich Nietzsche'nin kastettiği biraz da budur (Nietzsche, 2015, s.73). Bu süreçte tanrısal amaç geri plana itilmekte, yerini ise bireysel ve toplam mutluluk artışını sağlamayı hedefleyen bireysel amaç almaktadır. Aydınlanmanın kültürel ürünü olan modernite ile birlikte dünyayı anlamaya yönelik her türlü düşünce de modernizm üzerine inşa edilmektedir. İktisatta da modernist düşünce içinde ortak bir yöntem anlayışını (pozitivizm) benimseyen Neoklasik teori günümüzde hâkimiyetini sürdürmektedir. Nitekim Adam Smith'den Leon Walras'a giden süreçte doğa bilimlerinde yaşanan yoğun gelişmeler iktisat bilimini de etkilemiş, elinde soyutlama ve faydanın ölçülmesi gibi iki önemli güç bulunan Neoklasik teorinin, iktisadı fizik benzeri evrensel kurallara sahip bir bilim yapma yolunda önü açılmışıı. Bu süreçte bir sosyal bilim olan iktisat, ilişkileri salt insan-eşya düzeyine indirerek analizlerinde sosyal boyutu dışarıda bırakmıştır. 1950'lilerden itibaren ise özellikle modernizim ve pozitivist yöntem anlayışı yoğun eleştirilere tabi olmakta ve bu süreç postmodernizm olarak adlandırımaktadır. Bu süreçle birlikte tek doğrunun yerini çeşitleme ve farklılık, temsili bireyin yerini holistik yaklaşım almakta, bireylerin duygu, düşünce dünyaları ve kültürel bağlam tekrar analiz konusu edilmektedir.

Postmodernist bir ton taşıyan bu itirazın da dikkate alınması, iktisadın kendisine ilişkin kavrayışımızı kuvvetlendirecektir. Bu çalışmanın amacı da modernizmden postmodernizme bir süreç olarak iktisadın serüvenini ortaya koymaktır. Bu amaçla, çalışmanın ilk kısmında modernizm ve iktisat arasındaki ilişki incelenmiştir. İkinci kısımda iktisatta benimsenen hâkim yöntem anlayışı olan pozitivist yöntem, çalışmanın son bölümünde ise postmodernizm sürecinin iktisada olan etkisi analiz edilmiştir. Yapılan eleştiriler ise sonuç kısmında sunulmuştur.

\section{Modernizm ve İktisat}

Aydınlanma, geleneksel olarak İngiliz devrimiyle başlayıp Fransız devrimiyle bitirilen felsefi bir harekettir. Bu hareketin amacı, kötü ve köleleştirici olduğuna 
inanılan (mit, önyargı ve hurafeler gibi) eski düzenin kaldırılarak yerine iyi ve özgürleştirici olduğu kabul edilen aklın düzenini koymaktır. Dolayısıyla Aydınlanma Çağı aynı zamanda bir akıl çağıdır. Aydınlanmanın tarihsel arka planına bakıldığında ise on beşinci yüzyılın ortalarında Rönesans, on altıncı yüzyılda reform ve on yedinci yüzyılın ortalarından itibaren ise Descartes öncülüğündeki Kartezyen felsefe görülür. On sekizinci yüzyıl ise artık aydınlanma yüzyılı olmuştur denilebilir. Nitekim bu yüzyılı ayırt edici kılan da işte bu akıldır. Her ne kadar farklılıklar ve çeşitliliklerden bahsedilse de akıl, aydınlanma yüzyılının birleştirici ve merkezi noktalarından birini oluşturur. Aydınlanma ile ilgili yorumları ise iki ana kategoride toplamak mümkündür. Bunlardan ilki aydınlanmanın modernliğin kaynağı olduğu görüşüdür. İkinci görüş ise, Aydınlanmayı Fransız Devrimi ve sonrasıyla başlayan totaliter hareketlerin altyapısı olarak değerlendirmektedir ${ }^{1}$ (Cassirer, 1979; Çiğdem, 2009, s. 13-19).

Zygmunt Bauman, moderniteyi aydınlanmanın bir kültürel ürünü olarak görürken, bu ürünü kapitalizmin etkisiyle de toplumsal olarak benimsenmiş bir yaşam şekli olarak ifade eder. Bu sebeple, Fransız devrimi modernitenin doğuşuna zemin hazırlarken endüstri devrimi süreci de modernitenin iktisadi örgütlenme sürecinin gerçekleşmesini sağlamıştır (Çiğdem, 2004; Bauman, 2003, s. 9). Her ne kadar modern terimi geleneksel teriminin karşıtı olarak algılansa da modernin gelenekten kopuk olduğu anlayışı kabul edilebilir bir yaklaşım değildir. Kavram, geçmişle kopuk olmamızdan ziyade bize aktarılanlara daha az bağlı olmamızı ifade edebilir (Goody, 2008).

Modern terimi ilk defa 5 yy.' da Latince 'modernus' biçimiyle o dönemin Hıristiyan toplumlarını Romalı ve Pagan geçmişten ayırmak için kullanıldı (Habermas, 1996, s. 39). Modernite kavramının daha sonraları sosyal bilimler literatürüne girişi ise Hegel ile birlikte olmuştur. Hegel'in modernite tanımı ise geçmişi ve günümüzü birleştiren tarihsel bağlama işaret etmektedir (Sarıbay, 2004, s. 30). Habermas, Hegel'in modernite kavramının modern zamanlar anlamına

\footnotetext{
1 ... Hakim paradigma konumuna yükselme sürecinde Aydınlanma'nın evrensel özgürleşme vaadleri, paradoksal biçimde, farklılıkları bastıran, çoğulluk ve özgürlük sınırlayan bir totaliter metasöyleme dönüştü. Adorno, Horkheimer ve Lyotard'ın da belirttiği gibi, Aydınlanma artık totaliterdi. (Kara, 2001: 8)
} 
gelen yeniçağı ifade ettiğini dile getirerek, moderniteyi bu tarihsel döneme Rönesans ve Reform hareketlerini de ekleyerek Alman Hristiyan dünyasını, Roma ve Yunan antik dünyasından ayırmakla kalmayıp tüm Ortaçağ'dan bir kopuşu simgeleyen dönem olarak yorumlamıştır (Habermas, 1995, s. 5 'ten aktaran Sarıbay, 1995, s. 30).

Mike Featherstone (2005) da ilgili terimlerin belirli dönemlere gönderme yaptığını ifade eder. Örneğin, modernliğin Rönesans'la birlikte ortaya çıktığı vurgulanır. Modernlikten bugün anlaşılan şey ise geleneksel düzene karşıtlıktır. Yani modernlik toplumsal dünyanın iktisadi ve yönetsel olarak rasyonelleşmesidir (Featherstone, 2005, s. 21-22). Peter Wagner (2015) modernliğin, soyut özgürlük, araçsal rasyonalite, bireycilik ve Batı'ya özgü rasyonalite gibi terimlerle karakterize edildiğini ifade eder (Wagner, 2015, s. 270). Modernleşme terimi ise, gelişme sosyolojisinde iktisadi gelişmelerin geleneksel toplumsal yapılar ve değerler üzerindeki etkilerini göstermek için kullanılmıştır. Ayrıca modernleşme teorisi endüstrileşme, bilimin ve teknolojinin gelişimi, modern ulus devlet, kapitalist dünya piyasası, kentleşme ve öbür altyapısal öğelere yaslanan toplumsal gelişme aşamalarından bahsetmek için de kullanılır (Featherstone, 2005, s. 26). Modernizm ise, 20. yüzyıl başlarında ortaya çıkan ve son zamanlara dek çeşitli sanatlarda başatlık kuran sanat hareketleriyle ilintilendirdiğimiz üsluplara işaret eder (Featherstone, 2005, s. 27). Yine Jochen Schulte-Sasse (1986), modernizmin, modern dönemin kültürü ve dünya görüşünü yansıttığını yani modernizmin hem yüksek kültür hem de kitlesel kültürün çıktılarını kapsadığını ifade etmiştir (Schulte-Sasse, 1986, s. 6; Bilir, 2019, s. 224). Bell'e göre modernizm, kitlesel tüketimin hazcı kültürüyle bütünleşerek, geleneksel burjuva değerlerini ve Püriten etiği altüst eden hasmane bir kültürü zincirlerinden boşaltan çürütücü bir güçtür (Featherstone, 2005, s. 29).

Dolayısıyla modernizm, 19. yüzyıl ortalarında bilim, dil, aile, sanat ve toplum gibi birçok alanda etkisini göstermiş bir zihniyet yapısıdır. Söz konusu unsurların organizasyonu için bir kurallar dizisi geliştirilmiş̧ir. Bilimsel düzlemde bu kurallar metodoloji ile formüle edilmiştir. Metodoloji ve epistemolojinin beraber hareketi ile bilimin sınır ve içeriği tespit edilmiş olmaktadır. Modern bilimde bu işlem ayırımcllık (demarcation) ve kural koyuculuk (prescription) ile tanımlanır. Ayrımcllık 
ile bilim ve bilim dışı faaliyetler birbirinden ayrılırken, kural koyuculuk ile bilimin nasıl yapılması gerektiğine dair kurallar belirlenir. Böylelikle bilimsel alan organize edilmiş olur. Nitekim modernist düşüncenin ürettiği bu ayırımcılık ve kural koyuculuk neyin bilim neyin bilim olmadığına karar verir. Batı'da modernite süreci ile dünyayı algılamaya yönelik her türlü düşünce modernizm üzerine inşa edilir. Bu bağlamda modernizm, nesnel ve evrensel bir hakikat olduğunu ve bu hakikate akıl ve bilim ile erişilebileceğini kabul eden, rasyonel bir varlık olarak insanı savunan, akıl ve bilimi ilerlemenin tek yolu olarak gören epistemolojik tutumdur. Dolayısıyla hakikate ulaşmanın yolunun bilimden geçtiğini savunan pozitivizm ile modernizm arasında sıkı bir ilişki bulunmaktadır (Dulupçu, 1998; Bilir, 2019, s. 224). Nitekim modern bilimler aydınlanma geleneğinin izlerini taşırlar. Pozitivizm bu "izleri" belirgin bir bilgi kuramına dayandırıp sistematize eden ilk paradigmal çerçevedir. (Kara, 2001, s. 12) Günümüzde, bilimin resmi epistemolojisi ise, deneycilik (empirisizm) olmuştur (Rosenberg, 2020, s.25). Fakat Dogmatik Yanlışlamacilığa göre bilimsel teoriler de yanılabilirdir (Demir, 2019, s. 153). Bu mantığa göre, deney metodunun kendisinin de yanılabilir olduğu söylenebilir. Bunu iktisat yazınında aynı konuda zıt sonuçlara varan ekonometrik çalışmaların varlığı üzerinden gözlemlemek mümkündür.

İktisat disiplini içerisindeki farklı okullar arasında bazı metodolojik farklılıklar gözlenmektedir. Öte yandan, iktisatta modernist düşünce içinde hâkim bir yöntem anlayışının günümüzde de mevcudiyetini sürdürdüğü görülmektedir. Nitekim iktisatta benimsenen pozitivist yöntem bu doğrultuda olgulara ilişkin bilgilerin araştırılmasında temel yöntem olarak belirlenmiştir (Dulupçu, 1998; Kara, 2001, s. 20). Bu yöntem, normatif değerlendirmelerden ve etik duruşlardan ilke olarak bağımsızdır. İktisat, tıpkı fizik bilimi gibi objektif bir bilim olarak görülür (Friedman, 2008, s. 146).

\section{Iktisatta Pozitivizm}

Kökenleri 13. Yüzyılda Francis Bacon'a kadar uzanan pozitivist felsefenin temel amacı Aristocu metafiziğin yerine bilimsel deneyi koymaktır. Nitekim 17. yüzyılda Galileo ile birlikte pozitivist (olgucu) bilim anlayışı güçlenmiştir. 18. yüzyılda 
Hume'un bilimsel akıl yürütme yöntemini insan davranışlarına uyarlaması ise, başlatılan olgucu felsefenin dönüm noktası olmuştur. Nitekim 18. Yüzyılda aklın egemenliğini kabul eden Aydınlanma ile birlikte de pozitivist düşüncenin gelişimi güçlenmiştir. Aydınlanma sonrası ise Comte'un olguların toplanması ve betimleyici yasalar ile elde edilecek olan bilimsel bilginin üstünlüğünü ilan etmesiyle tüm disiplinlerde öznelliği aşacak bir görüş olarak pozitivist görüş pek çok alanda insan bilgisinin elde edilmesi için tek egemen yöntem olmuştur (Serdaroğlu, 2010, s. 13; Bell, 1981, s. 48).

Pozitivizme göre tüm bilimsel etkinlikler, doğrulukları deneyle kanıtlanan gerçek olaylardan yola çıkmalıdır. Bilim dünyasında bu görüşün büyük bir itibarı vardır. Ancak toplum bilimleri söz konusu olduğunda, pozitivizm üzerinde bazı soru işaretleri ortaya çıkmaktadır. Pozitivistlere göre doğa ve sosyal bilimler arasında konu açısından bir farklılık yoktur. Her iki alanda da kuramların kabulü ve reddi, aynı yönteme dayanarak, temel önermelere indirgeme yoluyla gerçekleşmektedir. Diğer bir ifadeyle öznellik bilim dışıdır (Acar, 2008, s. 334-35).

Modern düşüncenin ikili (dualistic) yapısı içerisinde gerçeklik, fiziksel-sosyal ayrımıyla ikiye bölünür. Ahmet Kara'ya göre bu ontolojik ikilem Kartezyen düalizmine bağlanabilir². Nitekim bilimsellik tartışmasının temel argümanları olan "değer'den bağımsızlık", "la-ahlakilik" "pozitif-normatif ayrımı" gibi temel argümanlar bu bağlamda üretilmiştir. Dolayısıyla bu pozitivistik ikilemler özü itibariyle Kartezyen ikilemlerdir. Bu doğrultuda gerçekliğin değerden tecrit edilmişliği, Batı'nın "bilgi"yi "hikmetten" ayıran düşünce matrisiyle ilişkilendirilebilir

\footnotetext{
2 Sadece olguların bilgisiyle sınırlı olan ve bu bilim anlayışııı tek doğruluk kaynağı olarak kabul eden pozitivizm, iktisat da dâhil olmak üzere Rönesans sonrası gelişen disiplinleri genel olarak etkisi altına almıştır. Bu yöntem anlayışı belirli bir ontoloji ve epistemolojiye sahip bulunmakta ve doğruluğu bu felsefi arka plana dayandırarak açıklamaktadır. Pozitivizmin, Rönesans sonrası bilimsel disiplinler üzerindeki etkisini anlamak için pozitivizmin dayandığı sacayaklarından biri olan Kartezyen anlayışa bakmamız gerekmektedir. Kartezyen anlayışta gerçeklik bölümlere ayrılabilmektedir. Gerçekliğin bu özerk bölünmesi, gerçekliğe ait bilgiye de yansır. Nitekim madde ve ruhun, fizik ve metafiziğin gerçeklik ve bilgileri de ayrı ve özerk kategoriler oluşturmaktadır. Kant'ta ortaya çıkan bu ikilemler kavranabilir ve kavramsallaştııılabilir olanlar (fenomen) ve kavranamaz ve kavramsallaştırılamaz olanlar (numen) şeklinde tanımlanır. Fakat pozitivist yöntemde fenomen olan dışında her şeyi yok sayan bir anlayış, bilimi fenomenlerle sınıllandırmakta yani nesnelleştirmekte, öznel değer ve normlardan soyutlamaktadır. Pozitivist yöntemin Kartezyen ikilemle kesiş̧iği bu söylem modern iktisadın değer yüksüz bir pozitif bilim olma yolunda ilerlemesine neden olmuştur (Kara, 2001).
} 
(Kara, 1996, s. 115). Öte yandan, normatif-pozitivist ikileminin sosyal bilimlerde en çok tartışıldığı alanlardan biri de iktisattır. İktisat ders kitaplarına bakıldığında iktisadi karar birimlerinin rasyonel davrandığı ve ekonomik çıkar maksimizasyonu ile hareket ettikleri varsayılır. Hâkim iktisat anlayışı yaptığı basitleştirici varsayımların yanında bu amaçlar üzerindeki sosyal, siyasal ve kültürel etkileri ayırarak (ceteris paribus) analizler yapabilmektedir. Ancak iktisadın bir sosyal bilim olması sebebi ile yapılan bu varsayımlar iktisadın soyut bir modelleme tekniğini benimsemesine neden olmuştur. Nitekim toplumsal ilişki düzeyi, fayda maksimizasyonlarını amaçlayan üretici ve tüketici arasındaki ilişkiye indirgenmiş, duygu, değer ve inançlar analiz dışı bırakılmıştır. Günümüz hâkim iktisat anlayışı da bu hazcı ilişki düzeyini benimseyerek bu ilişki düzeyini etkileyen diğer faktörleri analiz dışında tutarak modellerini kurmuştur (Demir, 1996). Yani, iktisat alanında pozitif iktisadın tartışmasız üstünlüğünden bahsedilebilir (Acar, 2008). John Neville Keynes'in yaptığı pozitif-normatif bilim ya da olan-olması gereken ayrımından hareketle (Friedman, 2008, s. 145) pozitif iktisadın da olanla ilgilendiği söylenebilir.

İktisadın bağımsız bir disiplin oluşu Adam Smith ile başlar. Ricardo ile birlikte iktisat daha çok teorik bir araştırma alanına dönüşmüştür. Nitekim Ricardo ile birlikte soyutlamanın gücünün iktisatçılar tarafından fark edilmesi iktisadın evrensel kuralları olan bir disiplin haline dönüştürülebileceği inancını kuvvetlendirmiştir. J.S. Mill ile birlikte faydacı felsefenin iktisat bilimine dâhil edilmesi ile a priori varsayımlara dayanan analizlerde iktisadın bireyi, faydacı felsefeden haz peşinde koşmayı; a priori yöntemden de amaçlara ulaşmak için gereken araçları rasyonel bir şekilde kullanmayı alacak ve bu yaklaşımı kendinden sonrakilere miras olarak bırakacaktır (Yılmaz, 2009). Dolayısıyla iktisadın fizik benzeri bir bilim olma sürecinin Smith'in homo economicusundan, Mill'in kârını artırma endişesi ile hareket eden homo economicusuna oradan da rasyonel tercih ile faydasını çoğaltmaya çalışan rasyonel bireye geçişle devam ettiği ifade edilmektedir (Sarfati, 2006). Ancak Daniel Hausman ve Michael McPherson (1994), diğer bilim dallarından farklı olarak iktisadın ahlak ve rasyonalite ile bağlantısı olduğunu ifade etmişlerdir. Birçok iktisatçı, iktisadı pozitif bir bilim olarak tanımlasa da iktisat, rasyonelliğin normatif teorisi etrafında şekillendirilir. Bu bağlamda Adam Smith, John Stuart Mill, Karl Marx, Frank Knight ve John Maynard Keynes gibi iktisatçllar 
hem siyasetçi hem de ahlak filozofudurlar. 18, 19 ve 20. yüzyıllara damgalarını vuran iktisatçıların bu ortak özellikleri şaşırtıcı olmamakta; çünkü iktisatçılardan aynı zamanda politika tavsiyeleri beklenmektedir (Hausman ve McPherson, 1994, s. 252). Nitekim Charles K. Wilber (2003) da iktisat ve etiğin birbirleriyle ilişkili olduğu, çünkü hem iktisatçıların hem de iktisadi aktörlerin kendi davranışlarını şekillendirirken aynı zamanda bir takım etik değerlere sahip olduğunu belirtmiştir. Bu noktada kimi yazarlar Adam Smith'in düşüncesine göre eğer rekabet yeterli derecede ise kişisel çıkarın toplum yararına olacağı ve daha da önemlisi eğer birçok insan genel ahlak yasasını davranışları için bir rehber olarak benimsediyse, yine benzer sonuçlara ulaşllabileceğini iddia etmiştir (Wilber, 2003). Smith'in Ahlaki Duygular Kuramı gerçekten böyle bir çıkarım içerir. (S)empati ${ }^{3}$ dinamiği ile işleyen doğal düzen sonucu bireyler kendi çıkarına davransalar da toplumsal faydadan alenen sapamazlar. Çünkü toplum içinde (s)empatiyi kaybetmek istemeyeceklerdir. Böylelikle kişisel çıkar motifi toplumun da yararını getirir.

Gerek Adam Smith gerekse de izinden gittiği ve "Bırakınız yapsınlar" yaklaşımının öncüsü olan Bernard Mandeville, eserlerinde tutkular ve toplumsal yarar konularına değinmişlerdir. Hatta Smith bu kavramların avantaj ve çıkar gibi daha da yumuşak kelimeler ile çekiciliğini arttırmıştır. Dolayısıyla ifade edilen bu tutkudan toplumsal faydaya geçiş sürecini beraberinde taşıyan yönlendirme düşüncesi on dokuzuncu yüzyıl liberalizminin önemli bir dayanağı olarak karşımızda durmaktadır. Yine Hegel de tutkularının peşinden giden insanların "yüksek bir dünya-tarihsel amaca hizmet ettikleri" düşüncesini ortaya atmıştır (Hirschman, 2008, s. 38-39).

19. yüzyıl sonu ve 20. yüzyılın başları iktisat biliminde önemli bir dönüşümü beraberinde getirmiştir. Artık tüketici davranışlarının açıklanması fayda üzerinden yapılmaya başlanmış ve marjinalistlerle birlikte faydanın ölçümüne yönelinmiştir. Nitekim fayda maksimizasyonu doğrultusunda yapılan soyutlamalarda homo economicus yani bir rasyonalite türetilmiştir. Bu rasyonalitenin belirli amaçlara varmayı sağlayacak bir araç olması, özgürce seçim yapan ve sağduyulu birey

\footnotetext{
${ }^{3}$ Smith bu kitapta sempatiyi de ifade etmek üzere empati kavramını kullanmaktadır.
} 
varsayımları ile açıkça çelişki göstermiş, bireyin tüm amaçlarının parasal kazançlara indirgenmesi sağlanarak ölçülemezlik probleminin ortadan kaldırılması amaçlanmıştır. Böylece klasik iktisadın ama daha çok Neoklasik iktisadın temel varsayımı olan iktisadi rasyonalite kavramı ile simgeleşen homo economicus öncelikle ekonomi politik bilimini daha sonra iktisadı ve buradan psikoloji, sosyoloji gibi sosyal bilimlerin geniş bir alanını etkisi altına almıştır (Sarfati, 2006). Dolayısıyla Neoklasik iktisadın metodolojik olarak temellendirilmesinde öne çıkan noktalar, yöntemsel bireycilik, yöntemsel enstrümantalizm (fayda maksimizasyonu) ve yöntemsel dengeciliktir. Bu noktada birey için esas olan fayda maksimizasyonudur. Bu bağlamda değerlendirilen birey ise ekonomik insandır. Bu insan tipi, ahlaktan bağımsız olarak hareket eder, bencil ve rasyoneldir (Eren, 2011, s. 17).

İktisatçıların pozitivist yöntem anlayışı ile doğa bilimlerinin sahip olduğu evrenselliğe ${ }^{4}$ ulaşmak istemeleri Neoklasiklerle birlikte ivme kazanmıştır. Jevons ${ }^{5}$, Walras $^{6}$ ve Menger'in 1870 'lerin başında ortaya koyduğu yaklaşımlar iktisadi analizde büyük bir dönüşüme neden olmuştur. (Yılmaz, 2009). Nitekim Jevons, Walras, Menger ve Marshall ekseninde geliştirilen iktisadın öznel değerler ve marjinal analize dayalı bir kolu olan Neo klasik iktisat, pozitivist yorumuyla, iktisadın bilimselleşme sürecinin ileri bir aşaması olarak ifade edilmektedir (Kara, 1996, s. 106) ${ }^{7}$. Bu noktada üretilen kavramsal kategoriler kadar dayanılan varsayımlar da önem arz etmektedir. Nesnel bilginin üretilmesinde dayanılan varsayımlardan biri karar birimlerinin rasyonel davranmasıdır. Bu noktada rasyonel insan, gerçek insanı değil, hipotetik bir insan kategorisini temsil etmektedir. Gerek marjinal analiz gerekse rasyonel insan varsayımıyla ilişkilerin nesnel-marjinal analizi mümkün olmaktadır (Kara, 1996, s. 117-118). Bu sürecin bir sonucu olarak, homo

\footnotetext{
${ }^{4}$....doğa bilimleri, değişen doğadaki değişmeyen yasaları araştırır. (Cevizci, 2017, s. 13). Aslında bu eğilimin nüvelerinin tarihsel yasalar arayan İbn-i Haldun'da ve daha sonra Marxist analizde de var olduğunu görmekteyiz (bkz. Kılınçoğlu, 2018).

${ }^{5}$ W. Stanley Jevons, iktisadın bir bilim olacaksa matematiksel bir bilim olması gerektiğin ifade eder (Jevons, 1888, s. 3).

${ }^{6}$ Leon Walras, iktisadın pür teorisinin her yönüyle fiziko-matematik bilimlere benzeyen bir bilim olduğunu belirtmiştir (Walras, 1965, s. 71).

${ }^{7}$ Her ne kadar Alfred Marshall (1920) Principles'da iktisadın biyoloji ile olan yakınlığını takdir etse de fizik ve mekaniğe daha yakın duran Neoklasik ekolün kurucuları arasında sayılır.
} 
economicus'un inşası hız kazanmıştır. Homo economicus olduğumuz şey değil, olmak istediğimiz şeydir. İktisat onu bir "daedalus" gibi inşa etmiştir. Homo economicus bu anlamda Nietzsche tabiriyle bir üst-insandır (ubermensch). Duygulardan ve çevre etkisinden arınmıs, cesurca haz peşinde koşan ve her zaman bir şekilde bunu maksimize eden insan tipidir.

1960 'lı yıllara gelindiğinde iktisatçılar arasında yapılan yöntem tartışmaları Neoklasik yaklaşım içerisinde homojen bir hal almıştır. Marshall'la birlikte klasiklerin "politik iktisadı" yerini "iktisat bilimine" bırakmıştır. Bu süreçte Alman Tarihsel Okulu ve Amerikan Kurumsalcı Okul yenilgiye uğramış ve iktisat öğretisinde Neoklasik anlayış tek olarak kalmışıtır (Keyder, 1979). Neoklasik iktisat, Marshall'dan itibaren tümdengelim yöntemine odaklanmıştır. Bu yönelimde matematiksel yöntemin ön plana çıkmasının da büyük payı bulunmaktadır. Tümdengelim yönteminden evrensel kanunlar çıkarılmakta ve bu yöntem mekanik ilişkileri gerektirmektedir. Dolayısıyla iktisatta da kanun olarak adlandıılan mutlak ilişkilerin ortaya çıkarılması bu bağlamda önem kazanmaktadır (Acar, 2008, s. 50-51).

Tarihsel, kültürel, toplumsal ve kişisel farklılıkları hesaba katmayan Neoklasik iktisat evrensel bir iktisadi analiz ortaya koyduğunu iddia etmektedir (Bilir, 2019). Diğer bir ifadeyle, Neoklasik iktisat, normatif-pozitif ikilemi içerisindeki bilimsel çözümlemeyi, gerçekliğin pozitif boyutuyla sınırlamakta, yani iktisat kuramında pozitif boyutu öne çıkarmaktadır. Nitekim bilimselliğin olgusal gerçeklik içerisinde var olduğunu savunan pozitivist yöntem Neoklasik kuramda iyice belirginleşmiştir. Dolayısıyla iktisadın değerden bağımsız olma özelliği bu bağlamda bir yöntem bilimsel ön gerekliliktir. Ahmet Kara'ya göre Neoklasik iktisadın uzun süren egemenliğinin altında yatan dinamik, Neoklasik kuramın ürettiği yöntembilimsel illüzyondur. Nitekim marjinal analizin, felsefi derinlikten yoksun iktisatçıları bir asır süren bir kış uykusuna yatırdığını ifade etmiştir. Neoklasik iktisatta ulaşılmak istenen bilgi tikel olanın bilgisidir ${ }^{8}$. Bu sebeple Neoklasik iktisat makrodan ziyade mikro

\footnotetext{
${ }^{8}$ Bu noktada tikelin bilgisine tümel bilgi vasıttasıyla ulaşılabileceği için evrensel doğru önermeler öne çıkmaktadır. $\mathrm{Bu}$ önermelerin formülasyonu ise soyut matematikle sağlanmaktadır. Bu sebeple Neoklasik iktisatta yoğun matematik kullanımı bir gerekliliktir (Kara, 1996, s. 118). Dolayısıyla ekonomik teoride formüle edilemeyen ve matematikleştirilemeyen faktörler iktisadın teorik yapısının dışına itilmiştir (Reinert, 2012).
} 
çözümlemelere odaklanır (Kara, 1996, s. 113-118). Dolayısılla, Neoklasik yaklaşım, klasiklerin politik iktisadının yerine marjinal analiz ve öznel yaklaşımı koyması ile birlikte günümüzün hâkim iktisat anlayışının kökeni olarak varlık göstermiştir. Ayrıca bu yaklaşım, üretim ve bölüşüm üzerindeki Klasik ve Marksist anlayışı mübadele ve etkinlik anlayışına kaydıran olguların oluşum süreçlerini veri alıp, olgular arası ilişkileri inceleyen yöntem olan pozitivist anlayışın da iktisattaki uygulayıcısı olmuştur (Kara, 2001). Pozitifliğin normatiflik karşısında, özellikle iktisatta değer yargılarının analiz dışında tutulmasında kullanıldığını görüyoruz. ìktisadın ahlaken yansız olması istenmekte ancak bu bile bir değer yargısı olması hasebiyle itiraz konusu olmaktadır. Bu noktada iktisadın bir sosyal bilim olarak değer yargılarından arındırılmasının ne kadar zor olduğu ortaya çıkmaktadır (Görün, 1979).

Ancak iktisat biliminde, doğa bilimlerinde yaşanan yoğun gelişmelerin de etkisiyle mutluluğun fayda, faydanın ise maddi refah artışı ile sağlanacağı görüşü iktisadın asıl sorunsalının faydanın ölçülmesi olduğunu ortaya koymuştur. Faydanın ölçülmesi ile birlikte iktisat artık çağın bilimi olma yolunda bir adım daha atacaktır. Neoklasik teori ile birlikte birey artık klasiklerdeki sadece çıkarlarını maksimize eden değil, önüne çıkan fırsatları hesaplayan (kardinal), sıraya dizen (ordinal) ve bunlar arasından tatmin düzeyini en yükseğe çıkaranı seçendir. Artık Neoklasik teorinin, ekonomi bilimini salt fizik bilimi gibi evrensel yasalara tabi olan bir bilime dönüştürmesinin önünde bir engel kalmamıştır. Nitekim elinde soyutlama ve faydanın ölçülmesi gibi iki güç bulunmaktadır. Artık fizikçinin laboratuvarda elde ettiği sonuçlara ekonomist soyutlamalar yaparak ulaşacaktır (Sarfati, 2006). Ancak Adam Smith'ten (Ahlaki Değerler Kuramı) ve Alfred Marshall (1920)'dan anladığımız gibi, mekanik sistem aslında biyolojik kökenlidir. Neoklasik iktisat, bir anlamda biyolojinin analitik mekaniğini kurma gibi destansı bir çabayı da ifade eder.

Diğer taraftan A.J. Snow (1924), iktisatçlların, psikolojik konsepti, ortodoks marjinal analize uydurmalarını, Paul Slovic ve Sarah Lichtenstein (1983) iktisadi analizlerdeki psikolojinin dikkate alınmamasını eleştirmektedir. Neyse ki davranışsal iktisat, bu eksiği de kapatma iddiasındadır. Herbert Simon, Neoklasik teorideki rasyonel davranan birey ve firmaların sırası ile fayda ve kârlarını maksimize edecekleri varsayımı günümüzde birey davranışlarını açıklamakta yeterli olmadığının altını çizmiştir. Yani 
rasyonalite ve fayda-kâr maksimizasyonu varsayımları ekonomik davranışları açıklamaktan uzaktır (Simon, 1986: 223). Milton Friedman ise, Neoklasik teorinin varsayımlarına yöneltilen yoğun eleştirilere ilişkin asıl önemli olanın varsayımlar değil sonuç olduğunu, bu nedenle teorinin sonuçlarına bakmamız gerektiğini belirtmiştir (Friedman, 2000; Friedman, 2008). Diğer taraftan ise, iktisat kuramlarını laboratuvar koşullarında sınama imkânı veren deneysel iktisat, 1970'li ve $1980^{\prime}$ li yıllarda iktisat metodolojisinde önemli bir yer tutan varsayımların gerçekliği ve sınanması tartışmasının da önemini kaybetmesine yol açmışır. Deneysel iktisat, iktisat yanında matematik, biyoloji ve psikoloji gibi farklı alanlarla da etkileşim halinde olduğundan disiplinler arası bir özellik göstermektedir. Benzer şekilde psikolojiyi analizlerine dâhil eden davranışsal iktisat, insanların gözlenen davranış kalıplarını analiz etme çabasındadır. Bu doğrultuda sınırlı rasyonellik ve bencillik gibi gerçekçi olan insan davranışları ile ilgilenilmektedir. Nitekim zamanla gelişen nöroiktisat da, bireysel kararlarda duygusallığın en az rasyonellik kadar önemli olduğunun altını çizmiştir (Eren, 2011, s. 40-43). Yine de bu yaklaşımların hepsi, Neoklasik iktisadı da içerisinde barındıran daha geniş bir sosyo-ekonomik paradigma olan ana akım iktisat olarak adlandırılır. Neoklasik iktisat öncülüğündeki ana akım iktisat dışında kalan yaklaşımlar da heterodoks olarak nitelendirilmekte ve ana akımın iktisat disiplini içerisinde yarattığı hiyerarşide geri planda kalmaktadır. Ana akım iktisadın bu bağlamda yarattığı saygınlığın sebebi kullandığı pozitivist metodolojidir. Diğer bir ifadeyle, sosyal bilimlerde de doğa bilimlerinde keşfedilenler gibi yasalara ulaşılmak istenmektedir (Bilir, 2019, s. 230231). Ancak konunun insan ve toplum olduğu bilimlerde değer yarglları ve ideolojilerin her zaman gözlem yapanı etkileyeceği gerçeği, pozitivist bilim anlayışına ciddi eleştirilerin yapılmasına da neden olmuştur (Özel, 2006).

Nitekim 20. yüzyılın başında fizik ve matematikte yaşanan gelişmeler pozitivizmin ulaştığı epistemolojinin temel dayanaklarını sarsmıştır. Nitekim Heisenberg'in belirsizlik ilkesi, görecelilik kuramı ve Eukleides'çi olmayan geometrinin ortaya çıkarılması, kuantum fiziği, dördüncü boyut ve moleküler biyolojide yaşanan gelişmeleri bu bağlamda ele almak mümkündür. Buradan hareketle gerçekçilikle ilgili değişen algı anti-pozitivist (olguculuk karşıtı) görüşleri ön plana çıkarmıştır. Bu karşı çıkış ve ortaya çıkardığı deneyimler de post modern çağa geçiş olarak ifade edilmiştir (Serdaroğlu, 2010, s. 15). Benzer şekilde kuantum fiziğinin bulguları, 
iktisadın gerçekliğiyle çelişmektedir. Maddenin sürekli değişim içindeki hali, evrenin eksiksiz biçimde gözlenmeyeceği ve araştırmanın sübjektif olacağı gibi çarpııı ifadeler pozitif bilime dolayısıyla bu yöntem anlayışını benimseyen iktisada yönelik eleştirilerin artmasına yol açmıştır (Acar, 2008, s. 42-43).

Bu noktada, normatif-pozitif bilim ayrımının savunulmaması, bilimsel araştırmalarda değer yargılarının oynadığı rolün farkına varılması, tek, doğru bir bilimsel yöntemin olmadığı, bilimsel teorilerinin varlığını değerlendirecek üzerinde anlaşılmış evrensel kuralların olmadığı, bilimsel aktivitelerin metafizik temellere dayanabileceği, kural koyucu metodolojilerin takip edilmeyebileceği, yine inanç, söylem (rhetoric) ve ikna yöntemlerinin matematik ve istatistik kadar önemli olduğu, sosyal bilimlerde bütün zaman ve mekânlarda geçerli çok fazla yasanın olmadığı gibi özellikler anti-pozitivist geleneği takip eden filozofların benimsedikleri ortak özellikleri ifade etmektedir (Beed, 1991, s. 470-471).

Bu geçiş ile birlikte modernizmin 'tek doğru' anlayışı tartışmaya açılmış ve modern bilim anlayışının diğer bilme biçimlerindeki hiyerarşik sıralamadaki önderliği sarsılmıştır. Bu ise çoğulcu söyleme bir kapı aralamak olarak yorumlanmıştır. Bu noktada modernist düşünce taraftarı iktisatçlların kanıta dayalı bilgiye ilişkin iddialarının doğru olmadığını söyleyen postmodernist düşünceyi benimseyen iktisatçılar önem kazanmaya başlamıştır (Serdaroğlu, 2010, s. 20). Ahmet Kara da Aydınlanmacı modernizmin hegemonyasının 20. yüzyılın son çeyreğinde ciddi bir sarsıntıya uğradığını ifade etmiştir. Postmodernizm olarak adlandırılan bu yeni akım, Aydınlanmacı modern bilim ve epistemolojilerin üzerine oturduğu tekil doğru ve tekil yanlış kategorilerine dayalı iki değerli mantık... Artık tatmin edici bulunamazd. Siyah ile beyaz arasında grinin binlerce tonu vardır; diğer renkler de çabası. (Kara, 2001, s. 8-9). Bir başka deyişle, toplumsal bilginin analog karakteri, artık sorgulanabilirdi.

\section{Modernizmden Postmodernizme İktisat: Değişim ve Dönüşüm}

Olguların bilimi olan pozitivist bilim, gerçekliği açıklamanın tek bir geçerli yöntemi olduğunu empoze eder. Duyum ve deneye dayanan bu gerçekliğin bilgisi 
de ona ait bilgiyle sınırlanmıştır. Gerçekliğe karşı takınılan inkârcı ya da agnostik tavır, tüm alternatif açıklama biçimlerini duyum, gözlem ve deneye dayanan bilimsel analiz dışına taşımıştır. Olguyu, varlığı doğrulanabilir tek gerçeklik kategorisi olarak gören pozitivizm, bilgi kümesini de ona ait bilgi ile sınırlamışır; dolayısıyla olgusal olan, yani deney ve gözlem yoluyla ölçülebilir olan dışında başka bir gerçeklik yoktur. Diğer bir ifadeyle pozitivistler, olmayan ya da bilinmeyen bir gerçekliğin bilgisinin de var olmayacağını ifade ederler. Bu sayede olgusal olamayan, bilimsel analiz dışına itilir. Böylece bilim, bilinebilir olanı inceleyecektir. Gerçekliğin tespitinde yapılan deney ve gözlemler nesnel (objektif) bir şekilde yapılır. Ancak insanın çevresini anlamasını sağlayan, her biri kendi içerisinde uyumlu, tutarlı olan bilgilenme yöntemleri ve bilgi türleri mevcuttur. Nitekim dinsel ve metafizik içerik taşıyan alternatif açıklama biçimleri bu bağlamda analiz dışında bırakılmıştır. Bu sebeple bilim bu bilgi türlerinden sadece biri olmasına rağmen sıralamanın en tepede olanı ve en itibarlısıdır. Bilimsel bilginin nesnellik-evrensellik, algılanabilirlik ve bilimsel yönteme sahip olma gibi özellikleri bilimsel bilgiyi diğer bilgilerden ayırmaktadır. Ayrıca bu özellikler modernist bir bağlamda değerlendirildiğinde daha anlamlı olmaktadır çünkü modernizmin iddialarını yansıtmaktadır. Her ne kadar anti-dini ve anti-metafizik olduğunu iddia etse de her soruyu cevaplayacak bilim olsa olsa bir bilim dini olacaktır. Diğer bir ifadeyle bilim olguları açıklamaktan öteye geçerek kendinden medet umulan bir hal almıştır. Yani bilime metafizik bir işlev yüklenmiş, bu nedenle bilim daha önce ifade edilen kendi varsayımlarıyla çelişmiştir. Ancak modernizme eleştirel yaklaşan postmodernist söylem tarafından bilimsel bilginin bu özellikleri eleştirilerek, herkes için bağlayıcı olan, mutlak, tüm bilgilerin üzerinde bir üst bilgi kategorisinin var olamayacağı, bilimin bağlam bağımlı olması gerektiği ileri sürülür. Bu nedenle modernizmin söylemine karşı oluşu postmodern söylemin geçmişte yoğun eleştirilere, küçümsemelere maruz kalmasına da neden olmuştur (Demir, 1996). Ancak günümüzde modernist bilim anlayışı sorgulanmakta ve modernizmi aşma çabaları postmodernizm anlayışına yoğunlaşmayı beraberinde getirmektedir (Kara, 1996, s. 108-111; Dulupçu, 1998). Feyerabend'in yöntem karşıtlığı da bu bağlamda değerlendirilebilir. Bilimsel araştırmada bile "tek tipçilikten" sıyrılmak, hem daha pratik hem de daha insanidir, çünkü daha özgürlükçüdür (bkz. Feyerabend, 1994 ve Feyerabend, 2017). Sonuçta, modernizm en nihayetinde 
kendi tepkisini de üretmiştir. Bu tepki postmodernizm olarak adlandırılmaktadır (Habermas, 1996, s. 44).

1950'lerin sonlarında ilk olarak kullanılmaya başlayan postmodernizm kavramının çeşitli tanımlamaları yapılmaktadır. İlgili literatürde postmodernlik, postmodernizm ve post-modernleşme gibi farklı kullanımları görmek mümkündür. Nitekim postmodernlik, aydınlanmanın akıl, gerçeklik, nesnellik, evrensel ilerleme gibi büyük anlatılarına kuşkuyla yaklaşan bir düşünce tarzıdır. Postmodernlik, dünyanın temelsiz, çeşitli ve dağınık kültür ve yorumlardan ibaret olduğunu ifade eder (Eagleton, 2011, s. 9). Postmodernleşme de yeni bir toplumsal düzene gönderme yapmak için kullanılmaktadır (Featherstone, 2005, s. 21-27). Postmodernizm ise sosyal-tarihsel periyodun kültürel yeniden üretim yapısına referansla açıklanmaktadır (Schulte-Sasse, 1986, s. 6; Bilir, 2019, s. 224). Eagleton (2011) postmodernizm ile postmodernlik arasındaki ayrımın dikkate alınmasının önemli olabileceğini ifade etmekle birlikte, postmodernizm terimini bu iki tanımlamayı birden kapsayacak şekilde kullandığını ifade etmiştir (Eagleton, 2011, s. 10). Bu bağlamda Eagleton (2011), postmodernizm terimini çağdaş kültürün bir biçimine gönderme şeklinde ifade etmiştir (Eagleton, 2011, s. 9).

Postmodernizmin bir üslup mu yoksa dönemleştirmeye bağlı bir kavram mı olduğu ya da aydınlanmanın her türlü düşüncesine karşı çıkan, ancak bu karşı çıkışı hep susturulan kesimlerin yanında olan devrimci bir potansiyel mi olduğu yoksa anti-kapitalizmin ticarileştirilmiş çeşidi mi olduğu şeklindeki sorular sorulmuş ve sorulmaya devam edilmektedir. Bu sorular ışığında Jean François Lyotard, üst anlatılara inanmamasını, Michel Foucault, kapitalizme ve onun baskılarına meydan okumasını, Stanley Aronowits ise ötekiler konusundaki duyarlılığını postmodernizmin en cazip yanları olarak görür (Harvey, 2010). Bu doğrultuda, postmodernizmin tek bir tanımını yapmak çok zor olduğundan, ancak diğer kavramlarla ilişkilendirilerek farklı tanımlara ulaşılabilmektedir. Postmodern anlayışta kesinlik ve mantık (facts and logic) kavramlarının oluşturduğu pozitif (positive) anlayışın yerini değerlere önem veren değer yüklü (value laden), normatif (normative) anlayış almaktadır (Tweeten and Zulauf, 1999, s. 9). Bu noktada Ernesto Screpanti (2000), modernist ontolojinin en önemli özelliğinin 
insan aklının evreni kavrama inancı olduğunu ifade eder. Postmodernizmde ise insan aklının kapasitesinin bu evrensel amaca ulaşmadaki eksikliği vurgulanmaktadır (Screpanti, 2000, s. 87).

Postmodernizmin gelişmesinin tarihi biraz daha incelendiğinde, Karl Marx, Sigmund Freud ve Friedrich Nietzsche'nin postmodern düşünce akımının ortaya çıkışında önemli katkılarının olduğu görülür (Tweeten ve Zulauf, 1999). Jean Francois Lyotard, Michel Foucault, Jacques Derrida, Louis Althuser, Jasques Lacon, Richard Rorty gibi düşünürler de postmodern teorinin gelişimine katkı sağlamışlardır. Bu düşünürler modernist düşüncenin tek doğruyu modelleyen yaklaşımlarını reddetmektedirler. Nitekim modernizmin modellerinin vurguladığı bu tek doğruya ulaşma yaklaşımı yerine postmodernizm, çeşitlilik ve farklılığa odaklanmaktadır. Modern kartezyen düşünce temelini oluşturan bağımsızlık (autonomy) ve akılcılık (rationality) gibi kavramlar postmodernizm süreci ile birlikte eleştiriye uğramıştır. Ayrıca postmodernist söylem tarafından rasyonel birey ile katı söylem (rhetoric) ve bilim (science) ayrımı sorgulanmıştır. Postmodernist düşüncenin sosyal yapısı, ayrıca kartezyen düşüncedeki 'ben'i merkeze alan anlayışın yerine 'ben'i merkezsizleştiren (decentering) anlayışa odaklanmıştır. Bu, iktisatta metodolojik bireycilik-holizm ayrımı şeklinde karşımıza çıkar. Ayrıca postmodern düşünce evrensel bilgiye ulaşma, bilim ve söylem ayrımı yaparak pür mantıksal bir bilim üretmeyi amaçlayan modernistleri de eleştirmektedir. Postmodernistler, iktisada şekil vermeye ilk önce modernist epitsemolojiyi eleştirerek başlamışlardır. Nitekim modernist ekonomistlerin denge, belirsizlik ve rasyonalite kavramları bu anlamda ciddi eleştirilere maruz kalmıştır. Bu anlamda postmodernistler teoride ve gerçek hayatta karşılaştığımız ekonomik olaylar arasındaki ayrıma (dichotomy) dikkat çekmişlerdir. Postmodernist ekonomistler ekonomik gerçekler olarak sunulan doğruların tutarsızlığını vurgulamıştır (Ruccio, 1991).

Nitekim modernist yapının ortaya koyduğu, deneyci, pozitivist-ontolojist yansıtmacı temellere dayanan bilgi, bilim ve insan anlayışları ile dünya görüşleri, postmodernizmin yapıbozum yöntemiyle bozulur (Serdaroğlu, 2010, s. 12). Bu bağlamda postmodernizmin disiplinler arası, evrimci ve yorumlayıcı olma 
özellikleri sürecin temelini oluşturmaktadır. Postmodernizm, bilgi üretim faaliyetinin çok çeşitli kaynaklardan beslendiğini ve söz konusu kaynakların da meşruluk açısından tam olarak karşılaştırılamayacağını savunmaktadır. Postmodernizm süreci ile birlikte modernizmin şekil verdiği ekonomik yaklaşım da değişim göstermektedir. Çağdaş ekonomistlerin modernitenin kısıtlamalarına karşı postmodern dönüşüme katılmaları söz konusudur. Ekonominin rasyonel insan varsayımından kurtarılması ve ekonominin psikoloji, antropoloji gibi bilimlere açılması postmodernizm sürecinin önemli bir özelliği olmaktadır (Ruccio, 1991).

Modernitenin temel hayali, bilim ve akıl ile insanın çevresini kontrol edebilmesidir. İnsanın çevresi ise fiziksel çevrenin yanı sıra, iktisadi alanı da barındıran bir sosyal çevreyi de içerecektir. Modernist iktisat anlayışı, insanın iktisadi çevresini kusursuz bir biçimde kontrol etme arayışı olarak görülebilir. Bu anlamda, iktisadın temsili bireye dayanması iktisadi çevreyi ölçme arzusunun ürünüdür. Çünkü iktisadi çevreyi kontrol edebilmek için, onu ölçülebilir ve tahmin edilebilir hale getirmek gerekecektir. Bu çaba ve bu arzu, kendisini ergodikliğin kabulünde bulur. Esasen bir istatistik terimi olan ergodiklik, bir değişkenin başlangıç koşulları ne olursa olsun uzun vadede tek (unique) ve istikrarlı (stable) bir forma yakınsamasıdır (Peters ve Adamou, 2018, s. 94). Örneğin, Neoklasik büyüme modelinden türetilen "Yakınsama Hipotezi" tipik bir ergodik modeldir?. Başlangıç kişi başı sermaye düzeyleri ne olursa olsun ekonomiler belirli bir kişi başı gelir düzeyine yakınsayacaktır. Ancak yakınsama sürerken meydana gelecek bir devrim (sanayi devriminin yaptığı veya yapay zeka devriminin söz gelimi yapabileceği gibi) ülkeleri birbirinden çok daha fazla farklılaştırabilir ve bu durumda yakınsama da geçerli olmayacaktır. Bu ergodik olmayan görüşün özüdür ve ekonominin evrilen bir yapı olmasından ileri gelmektedir. Ekonomiyi evrilen bir yapı olarak görmek ergodik olmayan görüşü beraberinde getirir çünkü evrimin nereye gideceği belli değildir. Hatta bu görüşe göre evrimin nereye varacağını tahmin etmek evrimin doğasına aykırıdır. Bu, aynı zamanda Thorstein Veblen'in Marxist deterministik tarih anlayışındaki sonu belli evrime yaptığı temel itiraz

\footnotetext{
9 Başka örnekler olarak doğal işsizlik oranı ve NAIRU gibi argümanlar da aynı ergodik zihniyetin ürünleridir ve mesela Post Keynesyen bakış açısından reddedilirler (bknz. Niggle, 2006, s. 409).
} 
noktasıdır (Hale, 2015, s. 124). Iktisatta, Kurumsalcılar ve Post-Keynesyenler, ergodikliğe karşı çıkmaktadır (Tauheed, 2011, s. 825).

Wallace C. Peterson'ın da belirttiği gibi rasyonalite varsayımı, politika modelleri kurmayı kolaylaştırmaktadır ve bu yolla "iktisadi ve sosyal çevreyi biçimlendirme" şeklindeki iddia kuvvetlenmiş olmaktadır (Peterson, 1977, s. 207). Bu iddia başı başına modernitenin iddiasıdır aslında. Dolayısıyla, modernist görüş, bilim ve teknik ile çevreyi insan uğruna şekillendirme hayali için homo economicus karakterine de muhtaçtır. Ancak son zamanlarda, davranışsal ve nöroiktisat gibi bilimcilik vurgusu yüksek alt disiplinler bile insan tekinin aslında o kadar da rasyonel olmadığını açıklıkla ortaya koymuş, ana akımın ise bunu kabul etmekten başka çaresi kalmamıştır.

Modernite ve iktisadi çevrenin ölçülüp biçilmesi (bundan sonra kodlanması) tartışmasına geri dönülecek olursa, simülasyon modellerinin bunun eğreti bir örneği olduğu görülür. Bazı zihinlerdeki simülasyon hayranlığı, içinde yaşadığımız evrenin de bir simülasyon olabileceği iddiasına kadar varabilmektedir. Ancak, Jean Baudrillard'ın da dediği gibi, "haritacıların çizdiği harita sonunda imparatorluğun topraklarına birebir eşit boyutlara sahip bir belgeye" dönüşmelidir. Yani bir sosyal çevrenin etkin bir şekilde simüle edilmesi için içindeki tüm bireylerin ve değişkenlerin (her şeyiyle birlikte) simülasyona katılması, bir diğer deyişle o çevrenin yeniden inşa edilmesi gerekecektir. Benzer şekilde bugün bazı fizikçiler dahi, simülasyonun fiziken imkânsızlığını öne sürmektedir (bkz. Galeon, 2017; Eck, 2017).

Günümüze gelindiğinde, yaşanan küresel kriz karşısında, iktisadın çözüm önerisi merak konusudur. Her ne kadar iktisattaki yeni yaklaşımlardan bahsedilse de, bu yeni yaklaşımların da modernitenin ürünü olduğu ifade edilmiştir. Dolayısıyla iktisattaki yeni yaklaşımların, değerden bağımsız bir değer bulma bulmacasına eşlik etmeye devam ettiği ancak er ya da geç hem felsefi hem de paradigmal anlamda yapı-çözücü katkılarla yüzleşmek zorunda kalacağı ifade edilmiştir (Arslan, 2015, s. 56-57). 
Bu noktada ortaya atılan en önemli soru küresel krizin iktisatçılar tarafından neden fark edilemediğidir. 18. yüzyıldan itibaren modern iktisat, doğa bilimlerine yakın bir şekilde kendisini tahmin edici bir disiplin olarak tanımlamış ancak küresel krizi gözlemlemede başarısız olmuştur. Karl Popper bu etkin tahminin karşı tarafında yer almışır. Ona göre her şeyin tahmin edildiği bir ortamda yeniliklerin ortaya çıkmayacağı çünkü bunların zaten yapılmış olacağı ifade edilir. Popper'in bu itirazına karşılık, rasyonel bireylerin bilgiyi kullandığı, istikrarlı ve tekrarlı bir düzende belirsizliğin hesaplanabilir risk ile yer değiştirileceği varsayılmaktadır. Şoklar ve belirsizlikler var olmakta ancak bunların birbirlerini dengelemesi neticesinde insanlar beklediklerini elde edeceklerdir (Skidelsky, 2009). Skidelsky'ye göre, İktisat, bu katı tahmin edici bilim algısını mekanik dünyadaki robotların etkileşimi hayali ile kazandı. Ancak, Newton fiziğinde kökenleri bulunan bu mekanik yapının insan davranışlarının kaynağının ne kadarını açıklayabileceği şüphelidir. Her ne kadar Keynes, politik iktisadın yolunu onlara açmış olsa da Keynes sonrasında iktisatçılar kendi disiplinlerini insan davranışları ile ilgilenen diğer sosyal bilimlerle ilişkilendirmediler... Aksine iktisatçılar karmaşık matematik ile maskelenmiş bir regresif araştırma programını tercih etmişlerdir. Yaşanan kriz ile birlikte Keynes'in özlü sözü tekrar hatırlandı. iktisat doğal değil ahlaki (moral) bir bilimdir (Skidelsky, 2009). Dolayısıla Robert Skidelsky'e göre, iktisat biliminin küresel kriz ile birlikte itibarını kaybetmesi birkaç nedene dayanmaktadır. Bunlardan ilki iktisadın tahmin edici bir bilime dönüşmesidir. Bu sayede sosyal bilim niteliğinden uzaklaşılmıştır. Yine iktisat ahlaki bir bilim olma niteliğini kaybetmiştir. Diğer bir ifadeyle, insan ve insani konulardan uzaklaşılmıştır. Bütün bunların arkasında ise iktisadın gereğinden fazla matematikleştirilmesi yatmaktadır (ilkokur, 2009). Bu noktada Charles Goodhart'ın dediği gibi "Dinamik stokastik genel denge modelleri benim bir iktisatçı olarak ilgilendiğim her şeyi dışarıda bırakıyorlar" (Özatay, 2009) ifadesi anlamlıdır. Yine benzer bir tartışmayı emek piyasalarında da gözlemlemek mümkündür. Reel ücretler ve bölgesel işsizlik arasındaki negatif ilişkisinin ekonominin ampirik bir yasası olarak gören (emprical law of economics) görüş aslında fizik benzeri bir genel yasa elde etme çabasındadır. Philip Mirowski'nin (1989) ekonomiyi, sosyal fizik olarak tanımlaması ise konuyla birebir örtüşmektedir (Nijkamp ve Poot, 2005, s. 422). Benzer şekilde finansal piyasalarda da hisse senetlerinin doğru bir şekilde fiyatlanacağı beyan 
edilmektedir. Bu ifade kendisini finansal piyasalardaki etkin piyasa hipotezinde göstermektedir. Etkin Piyasa Hipotezi, bankacıların üretilen matematiksel tahmin modellerine körü körüne bağlanmasına yol açmıştır. Yine benzer şekilde etkin piyasa hipotezi finansal piyasaların çökeceğine yönelik beklentilerin azalmasına yol açmıştır. Bu noktada yine bu hipotez Alan Greenspan'ı yaşanan süreci dünya çapındaki riskin oldukça düşük olduğu şeklinde tanımlamaya sevk etmiştir (Skidelsky, 2009). Bu nedenle iktisadın, karşı karşıya kaldığı, krizler, çevre kirliliği, doğal kaynakların tükenmesi ve sosyal çelişkiler gibi konularla iktisadın hâlihazırda mevcut araçlarılla mücadele edilemeyeceği gözlenmiştir. Bu bağlamda iktisadın yaşanan problemleri çözecek ve gelişmeye açık bir yapılanmaya ihtiyacı vardır. Nitekim bilgi teknolojilerindeki gelişmeler ve psikoloji gibi alanlardaki bulgular da bu yöndeki değişimin habercisi olmaktadır (Acar, 2008, s. 24). Bu noktada, Gregory Mankiw, modern makro iktisadı 19. yüzyılın tıp bilimine benzetmekte, dolayısıyla iktisadın yanlış modellere dayanan politika önerilerinin ekonomilerin aleyhine sonuçlar doğurabileceğine dikkat çekmektedir. Bu nedenle de iktisatçı zarar vermemeye daha çok dikkat etmelidir (Mankiw, 2014).

\section{Tartışma ve Sonuç}

Akıl ve bilimin kadim olanın (kadim olan ile burada yerine göre dinsel olanın, yerine göre de feodal olanın anlaşılması mümkündür) yerini alması aydınlanma düşüncesinin temelini oluşturmakta, modernite ise aydınlanmanın kültürel ürünü olarak aklı merkezine almaktadır. Akılcı bireyin alacağı kararlar bireysel faydanın maksimizasyonunu sağlamaya yönelik olmakta, bu da toplumsal faydayı maksimize etmektedir. Ayrıca bu akılcı ve özgür bireyin sınırsı ihtiyaçları sınırlı kaynaklarla karşılama konusunda kendisine müdahale edilmediği sürece ihtiyaçlarını en iyi şekilde karşılayacağı yani dengenin kendiliğinden gerçekleşeceği varsayılmaktadır. Ancak günümüzün hâkim iktisat anlayışı olan Neoklasik analiz insan-insan ve insantoplum ilişkilerini analiz dışı bırakmış salt insan-eşya ilişkisine yönelerek asıı bir sosyal bilim olan iktisadı sosyal içerikten yoksun bırakmıştır.

Yaşanan savaşlar, ekonomik krizler, fakirlik, kıtlk gibi süreçler hâkim düşünce akımına muhalif akımların ortaya çıkmasına yol açmıştır. İşte postmodernizm de yukarıda 
bahsettiğimiz süreçlerin modern düşüncenin ürünü olduğuna inanmakta ve modernizme bir tepki olarak ortaya çıkmaktadır. Ekonomi alanında hâkim olan Neoklasik düşünce ve pozitivist yöntem anlayışı bu bağlamda postmodern düşünce tarafından sorgulanmaya tabi olmaktadır. 1950'li yılların ortalarından itibaren modernizme tepki olarak doğan postmodernizm süreci ilk etapta yoğun eleştirilere uğrasa da zamanla etkisini hissettirmiş ve modernizm karşısına alternatif bir söylem olarak çıkmıştır.

Postmodernist düşünürler modernist düşüncenin evrensel doğruya ulaşmak için yaptığı soyutlama ve varsayımları reddetmekte bunun yerine çeşitlilik ve farklılığa odaklanmaktadır. Modernist ekonomistlerin denge, belirsizlik ve rasyonalite kavramları bu anlamda ciddi eleştirilere uğramıştır. Bu anlamda, özü itibariyle aslında modernist bir tasavvur olan, ama gerçeğe pek de uygun görünmeyen homo economicus yaklaşımının terk edilmesi gerekmektedir. Gerçekten de iktisattaki son dönem yaklaşımlar, davranışsal iktisat ve nöroiktisat dâhil, homo economicusu aşındırıp durmaktadır. O'nun iktisadi düşünce sahnesinden silinmesi çok da uzak görünmemektedir. Postmodernizm, metodolojik bireycilik yerine daha holistik anlayışları ön plana çıkarır. Kurumsalcı okul ve Post Keynesyen okulun bu yeni anlayışa katkı sağlayacağı beklenebilir. Ayrıca, iktisadi hayatı, ahlak, zihniyet, kültür gibi unsurlarla harmanlayarak analiz eden Alman Tarihçi Okulu gibi Yorumsamacı yaklaşımların ve İktisat Sosyolojisinin postmodern dönemde etkilerini artırmaları söz konusudur. Türkiye akademik camiasında bu anlamda, Sabri Ülgener'in açtığı Yorumsamacı İktisatta Zihniyet çalışmalarının tekrar ele alınarak ilerletilmesi iktisadın postmodern dönemdeki yeni yönelimlerine uygun bir gelişme olacaktır.

\footnotetext{
Hakem Değerlendirmesi: Dış bağımsız.

Yazar Katkıları: Çalışma Konsepti/Tasarım- H.B., G.B.; Yazı Taslağı- H.B., G.B.; İçeriğin Eleştirel İncelemesi- H.B., G.B.; Son Onay ve Sorumluluk- H.B., G.B.

Çıkar Çatışması: Yazarlar çıkar çatışması bildirmemiştir.

Finansal Destek: Yazarlar bu çalışma için finansal destek almadığını beyan etmiştir.

Peer-review: Externally peer-reviewed.

Author Contributions: Conception/Design of Study- H.B., G.B.; Drafting Manuscript- H.B., G.B.; Critical Revision of Manuscript- H.B., G.B.; Final Approval and Accountability- H.B., G.B.

Conflict of Interest: The authors have no conflict of interest to declare.

Grant Support: The authors declared that this study has received no financial support.
} 


\section{Kaynaklar/References}

Acar, G. T. (2008). Iktisadı değiştirmek: Neoklasik iktisada eleştirel bir yaklaşım. İstanbul: İletişim Yayınları.

Arslan, M. (2015). İktisatta yeni yaklaşımlar, heterodoks iktisat ve yapıçözüm: Karmaşıklığın bilimi ve postmodern bilim söylemi bağlamında bir değerlendirme. E. Eren \& M. Sarfati (Eds.), iktisatta Yeni Yaklaşımlar kitabı içinde (s.47-57). İstanbul: İletişim Yayınları.

Bauman, Z. (2003). Yasa koyucular ile yorumcular. (Kemal Atakay, Çev.). İstanbul: Metis Yayınları.

Beed, C. (1991). Philosophy of science and contemporary economics: An overview. Journal of Post Keynesian Economics, 13(4), 459 - 494.

Bell, D. \& Kristol, I. (2003) Models and reality in economic discourse in the crisis in economic theory (Ed.). New York: Free Press.

Bilir, H. (2019). Postmodernizmin iktisada yansımaları. Felsefe ve Sosyal Bilimler Dergisi, 27, 221-241.

Cassirer, E. (1979). The philosophy of the enlightenment. (Fritz C.A. Koelin \& J. P. Pettegrove, Trans.). Princeton: Princeton University Press.

Cevizci, A. (2017). Aristoteles hayatı ve eserleri. (Furkan Akderin, Çev.). Nikomakhos'a Etik kitabının içinde. İstanbul: Say Yayınları.

Çiğdem, A. (2004). Bir imkan olarak modernite, weber ve habermas. İstanbul: İletişim Yayınları.

Çiğdem, A. (2009). Aydınlanma düşüncesi. İstanbul: İletişim Yayınları.

Demir, Ö. (1996). Iktisatta yöntem tartışmaları. Ankara: Vadi Yayınları

Demir, Ö. (2009). Bilim felsefesi. Ankara: Vadi Yayınları.

Demir, Ö. (2019). iktisat metodolojisi. Bursa: Sentez Yayınları.

Dow, C. S. (1991). Are there any signs of postmodernism with economics? Methdos, 3(1) (June), 81-5.

Dulupçu, A. M. (1998). Modernizm - iktisat - retorik ve metafor üzerine post - epistemolojik bir deneme. Süleyman Demirel Üniversitesi İktisadi ve Idari Bilimler Fakültesi Dergisi, 3, 15-34.

Eagleton, T. (2011). Postmodernizmin yanılsamaları. (Mehmet Küçük, Çev.). İstanbul: Ayrıntı Yayınları.

Eck, A. (2017). Physicists confirm that we're not living in a computer simulation. https://www.pbs.org/ wgbh/nova/article/physicists-confirm-that-were-not-living-in-a-computer-simulation/ (Erişim tarihi: 05.07.2019).

Eren, E. (2011). Yeni iktisatta ortak noktalar. İçinde E. Eren \& M. Sarfati (Eds.), iktisatta yeni yaklaşımlar (ss.13-45). İstanbul: İletişim Yayınları.

Esgün, T. G. (2006). Postmodernizme rağmen aydınlanma. Kaygı. Uludağ Üniversitesi Fen-Edebiyat Fakültesi Felsefe Dergisi, 0(6), 96-103.

Featherstone, M. (2005). Postmodernizm ve tüketim kültürü. (M. Küçük, Çev.). İstanbul: Ayrıntı Yayınları.

Feyerabend, P. K. (1994). Against method. London: Verso.

Feyerabend, P. K. (2017). Özgür bir toplumda bilim. (A. Kardam, Çev.). İstanbul: Ayrıntı Yayınları.

Friedman, M. (2008). The methodology of positive economics. In D. M. Hausman (Ed.), The Philosophy of Economics: An Anthology (s. 145-178). Cambridge University Press. 
Galeon, D. (2017). Sorry, Elon. Physicists say we definitely aren't living in a computer simulation. https://futurism.com/sorry-elon-physicists-say-we-definitely-arent-living-in-a-computersimulation, (Erişim tarihi: 05.07.2019).

Goody, J. (2008). Kapitalizm ve mdernlik. (I. Durdu, Çev.). İstanbul: Küre Yayınları.

Görün, F. (1979). Iktisatta kapsam ve yöntem. Ankara: Orta Doğu Teknik Üniversitesi Yayınları.

Habermas, J. (1996). Modernity: An unfinished project. In M. Passerin d'Entrèves \& Seyla Benhabib (Eds.), Habermas and the unfinished projet of modernity (pp. 38-58). Polity Press.

Hale, E. E. (2001). Lecture notes from economics 327: Comparative economic systems. In W. J. Samuels (Ed.), Edward Everett Hale: The Writings of an Economic Maverick - Research in the History of Economic Thought and Methodology (pp. 105-138). Emerald Group Publishing Limited: Bingley.

Harvey, D. (2010). Postmodernliğin durumu. (Sungur Savran, Çev.). İstanbul: Metis Yayınları.

Hausman, D. \& McPherson, M. (1994). Economics, rationality and ethics. In D. M. Hausman (Ed.) The philosophy of economics: an anthology (pp. 252 - 274). Cambridge University Press.

İlkorur, K. (2009, 24 Aralık). İktisat tartışmaları ... (2), Radikal gazetesi. http://www.radikal.com.tr/ yazarlar/korkmaz-ilkorur/iktisat-tartismalari-2-970846/ (Erişim tarihi: 4.03.2021).

Jevons, S. W. (1888). The theory of political economy. London: Macmillan.

Kara, A. (1996). Neoklasik iktisatta pozitivist metodoloji: Eleştirel bir yaklaşım. Ö. Demir (Ed.). iktisatta Yöntem Tartışmalar içinde (s. 105-131). Ankara: Vadi Yayınları.

Kara, A. (2001). Iktisat kuramında pozitivizm ve post modernizm. Ankara: Vadi Yayınları.

Keyder, Ç. (1979). İktisatta kapsam ve yöntem. içinde fikret görün (Ed.) Iktisatta kapsam ve yöntem: Seçme yazılar. Ankara: Orta Doğu Teknik Üniversitesi Yayınları.

Kılınçoğlu, D. T. (2018). İbn Haldun: Sistem kuran düşünür. İçinde A.A. Eren ve E. Kırmızıaltın (Ed.). iktisat sosyolojisi (ss. 41-82). Ankara: Heretik Yayınları.

Lyotard, J. F. (2000). Postmodern Durum: Bilgi Üzerine Bir Rapor. Çev. Ahmet Çiğdem. Ankara: Vadi Yayınları.

Mankiw, G. (2014, March 23rd). When the scientist is also a philosopher. The New York Times.https:// www.hks.harvard.edu/centers/mrcbg/programs/growthpolicy/when-scientist-also-philosopher. (Erişim Tarihi:18.06.2021).

Marshall, A. (1920). Principals of economics. London: MacMillan.

Nietzsche, F. (2015). Böyle söyledi zerdüşt. (Mustafa Tüzel, Çev.). İstanbul: İş Bankası Yayınları.

Niggle, C. (2006). Evolutionary keynesianism: A synthesis of institutionalist and post-keynesian macroeconomics. Journal of Economic Issues, 40 (2), 405-412.

Nijkamp, P. \& Poot, J. (2005). The last word on the wage curve. Journal of Economic Surveys, 19 (3), 421-450.

Friedman, M. (2000). Pozitif iktisadın metodolojisi (Çev. Mehmet Orhan). İçinde Ö. Demir (Ed.). Devlet, rekabet, mülkiyet ve iktisat (11-60). Adapazarı: Değişim Yayınları.

Özatay, F. (2009). İktisat kuramı deprem geçiriyor. Radikal gazetesi. http://www.radikal.com.tr/ yazarlar/fatih-ozatay/iktisat-kurami-deprem-geciriyor-970305/ (Erişim tarihi: 5.03.2021). 
Özel, H. (2006). iktisat, ideoloji ve iktidar [Konuşma metni]. Bilim ve İktidar başlıklı konferansta yapılan konuşma, Hacettepe Üniversitesi, Ankara. Erişim adresi: http://yunus.hacettepe.edu. tr/ ozel/Bilim_iktidar_Karaburun.pdf (Erişim tarihi: 5.03.2021).

Peters, O. \& Adamou, A. (2018). Ergodicity economics [Blog yazısı]. Erişim adresi: https:// ergodicityeconomics.files.wordpress.com/2018/06/ergodicity_economics.pdf (Erişim tarihi: 5 . 03. 2021)

Peterson, W.C. (1977). Institutionalism, Keynes and the real world. Journal of Economic Issues, 11:2, 201-221.

Reinert, E.S. (2012). Neo-classical economics: Atrail of economic destruction since the 1970s, RealWorld Economics Review, 60, 2-17.

Rosenberg, A. (2020). Bilim felsefesi: Çağdaş bir giriş. Ankara: Dipnot Yayınları.

Ruccio, D.F. (1991). Postmodernism and economics. Journal of Post Keynesian Economics, 13(4), 495 510.

Sarfati, M. (2006). Rasyonalite ve neoklasik kuram. Ekonomik Yaklaşım, 16(57), 103-130.

Sarıbay, A. Y. (2004). Modernitenin ironisi olarak globalleşme, İstanbul: Everest Yayınları.

Schulte-Sasse, J. (1986). Introduction: Modernity and modernism, postmodernity and postmodernism: Framing the Issue. Cultural Critique, 5, 5- 22.

Screpanti, E. (2000). The postmodern crisis in economics and the revolution against modernism. Rethinking Marxism, 12(1), 87-111.

Serdaroğlu, U. (2010). Feminist iktisatın bakışı postmodernist mi? Ankara: Efil Yayınevi.

Simon, H. (1986). Rationality in Psychology and Economics. The Journal of Business, 59(4),S209-S224.

Skidelsky, R. (2009, 15 Aralık). Economic Theory: How to rebuild a newly shamed subject. Financial Times. https://www.ft.com/content/098e5930-e843-11de-8a02-00144feab49a (Erişim tarihi: 5.03.2020)

Slovic, P.\& Sarah, L. (1983), Preference reversals: A broader perspective. The American Economic Review, 73(4), $596-605$.

Smith, A. (2006). Milletlerin zenginliği. (H. Derin, Çev.). İstanbul: Türkiye İş Bankası Yayınları.

Smith A. (2018). Ahlaki duygular kuramı. (D. Kızılay, Çev.). İstanbul: Pinhan Yayınları.

Snow, A. J. (1924). Psychology in economic theory. The Journal of Political Economy, 32(4), 487 - 496.

Tauheed, L. F. (2011). A proposed methodological synthesis of Post-Keynesian and Institutionalist Economics. Journal of Economic Issues, 45(4), 819-838.

Tweeten, L. \& Zulauf, C. (1999). The challenge of postmodernism to applied economics. American Journal of Agricultural Economics, 81(5), 1166 - 1172.

Wagner, P. (2015). Interpretations of modernity and the problem of World - making. Papers: Revista de Sociologia, 100(3), 267-279.

Walras, L. (1965). Elements of pure economics. (W. Jaffe, Çev.), London: George Allen and Unwin LTS.

Wilber, C.K. (2003). Ethics and economic actors. Post - Autistic Economics Review, 21(3).

Yılmaz, F. (2009). Rasyonalite iktisat özelinde bir tartışma. İstanbul: Paradigma Yayınları. 